\title{
Changes in Learning Style: Does it Change?
}

\begin{abstract}
Akbar, S.
Abstract

Background: Learning styles can change over time. Changes in learning styles can be influenced by the learning environment that students accept. The dominant learning style provides an overview of students' adjustment in the learning environment. The studies aim to analyze the changes in the learning styles of medical students in the Faculty of Medicine over the past three years.

Methods: A cohort study was conducted to medical students in 2016 and 2017 ( $n=107)$. All students were asked to fill out Kolb learning styles questionnaire twice, first during the first semester and the second in semester V. A comparative analysis was conducted to measure the significance of changes in learning styles.

Results: The most learning styles in the first semester were Diverger (40.4\%), followed by Converger (24.6\%), Assimilator (19.3\%), and Accommodator (15.8\%). In the fifth semester still dominated by Diverger (33.3\%), Converger (28.1\%), Accomodator (21.1\%), and Assimilator (17,5\%). There was no significant difference found between student learning styles in the first year and third year $(p>0.05)$.
\end{abstract}

Conclusion: There is no difference in the dominant learning style between the first year and the third year. But there are changes in student learning styles over time.

Keywords: Kolb, Learning Style, Change.

\section{Introduction}

Experiences that somebody received will contain information about the interaction between a person with the environment. The way that learners do in terms of processing information is known as learning styles (Kolb, 2015). David A. Kolb conveyed 4 learning styles in processing information from experience, namely: diverger, assimilator, converger, and accommodator (Kolb, 2015).

Learning styles can change over time. Changes in learning styles based on experiential learning theory can occur as a result of experiences gained from time to time. Here the role of the curriculum is considered to influence changes in the learning experience received by students.

Medical Education Unit staff at Medical Faculty of UISU

Corresponding Author: Dr Surya Akbar

Faculty of Medicine Universitas Islam Sumatera Utara

Jalan.

STM, No. 77, Kelurahan Suka Maju, Medan Johor

Email:dr.akbar9@gmail.com

DOI: http://doi.org/10.4038/seajme.v14i2.249
The series of learning activities in the curriculum will make a different learning experience for students where was affected the student's learning style.

This study aims to determine the dominant learning styles of medical students in both the first and third years. This study also aims to determine changes in learning styles in firstyear and third-year medical students.

\section{Participants}

Respondents in this study were all students of the Medical Faculty of UISU who came from two different year classes, namely 2016 and $2017(n=107)$. In this research, student learning styles will be measured twice, which is in the first semester (first year) and the fifth semester (third year). 


\section{Methods}

A cohort-prospective study was conducted in this research. Kolb Learning Style Inventory was used for determining students learning style. The data analysis begins by tabulating the learning style data of students in the semester I and semester V. The researcher then excludes students who have incomplete data (if there is only one learning style data in either semester I or semester V).

This research has been approved by the Ethics Committee of the Medical Faculty of UISU.

\section{Results}

A total of 57 students participated in this study (response rate: $53,27 \%$ ), which is 16 students $(28,1 \%)$ from 2016 , and 41 students $(71.9 \%)$ from 2017.

The most learning styles of students while in the first semester were diverger as many as 23 people $(40,4 \%)$ likewise, the learning styles in the fifth semester were mostly diverger as many as 19 people $(33,3 \%)$. However, if you look at the cross table of student learning styles, only 9 students still have diverger learning styles both in the semester I and semester V (15.8\%).

The comparative test using the Kolmogorov Smirnov $Z$ test concluded that there was no significant difference between student learning styles in the semester I and semester V $(p>0,05)$.

\section{Discussion}

The dominant learning style in this study is Diverger, as many as 23 people $(40,4 \%)$ in the semester I and 19 people $(33,3 \%)$ in semester $\mathrm{V}$. Research conducted at medical students of UCSI Malaysia university also shows the same results (Tha and Khin, 2015). The students with diverger learning style will view experiences from various perspectives, so it can provide a comprehensive picture. The characteristics like this are very suitable for learners who have just entered a new situation or learning environment. Maybe this is also the reason why most learning styles from this study are divergers.

In contrast to this study, several studies have shown that the learning styles of medical students, especially the first or second years, have an assimilator learning style (Engels and De Gara, 2010; Bitran et al., 2012). This learning style is usually found in groups of thinkers who try to explain an experience or phenomenon. Medical students who try to understand a medical science will form a concept in their mind. That is, in this process, they will use an assimilator learning style to be able to form these concepts in their minds.

The diverger remains the learning styles that are mostly owned by third-year students. The comparative analysis did not show a significant difference. It seems that it is no difference in student learning styles. However, almost all students have changes in learning styles (table 1).

Table 1: Cross Table of Students Learning Style

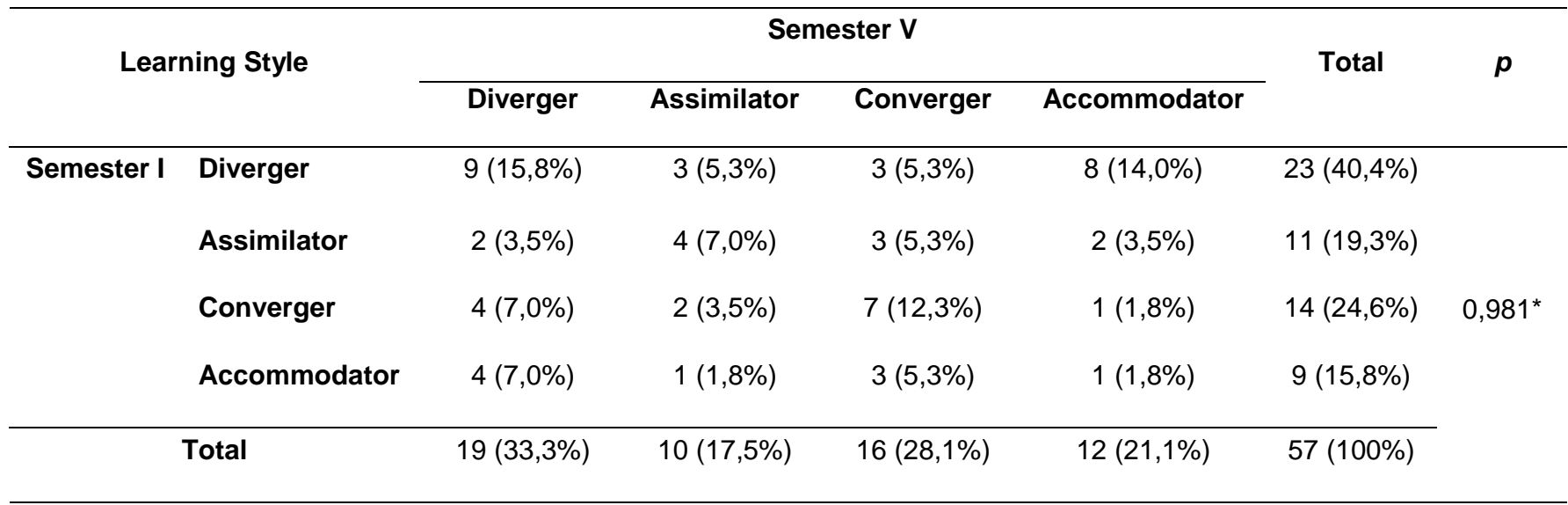

*) Kolmogorov-Smirnov Z 
Research on medical students shows that students' learning styles do not change from the first year to the third year, but changed in the seventh year (Bitran et al., 2012). Research in the surgical department shows that there are differences in learning styles between medical students and surgical residents, but there is no difference between surgical residents and supervisors (Engels and De Gara, 2010). It can be assumed that the assessment plays a role in influencing changes in learning styles. The form and depth of the assessment will encourage learners to accomplish the targets of the assessment (Scott, 2020). Assessment in the form of skills (such as DOPS, OSCE) will direct students to master a skill. Assessment in the form of diagnosis and management of diseases will direct students to mastery analysis and problem-solving skills. This is what we called with assessment drives learning. Changes to these learning targets will indirectly change the way they learn (learning styles).

This study has several limitations, including the small number of respondents $(n=57)$; other variables such as age, gender were not measured; the form of curriculum and assessment is not measured; results are limited to UISU medical students.

\section{Conclusion}

The dominant learning styles of UISU medical students in both the first and the third year did not differ significantly. The diverger is the dominant learning style in both the first and third years. However, there are changes in learning styles in students.

\section{Acknowledgments}

The authors would like to thank dr. Tezar Samekto Darungan, MMedEd and dr. Rosyadi Aziz Rahmat, M.Pd.Ked for their enthusiasm and support of this research.

\section{Conflict of Interest}

The authors declare no conflict of interest.

\section{Reference}

Bitran, M., Zúñiga, D., Pedrals, N., Padilla, O. and Mena, B. (2012) Learning styles of medical students change along the study program: from 'thinking and watching' to 'thinking and doing'. Canadian Medical Education Journal, 3(2), pp.86-97.

Engels, P. T. and De Gara, C. (2010) Learning styles of medical students, general surgery residents, and general surgeons: Implications for surgical education. BMC Medical Education, 10(51), pp. 1-6.

Kolb, D. A. (2015) Experiential Learning. 2nd ed. New Jersey, USA: Pearson Education.

Scott, I. M. (2020) Beyond 'driving': The relationship between assessment, performance and learning. Medical Education, 54, pp. 54-59.

Tha, M. K. and Khin, N. (2015) Learning Styles of Undergraduate Medical Students: Using the Kolb Learning Style Inventory. MedEdPublish, 4, pp. 1-10. 